\title{
Electric and Magnetic Fields for the Proposed Microstrip Antenna with DGS for Breast Cancer Detection
}

\author{
M. N. Truna \\ Department of Electrical and \\ Electronics Engineering \\ University Malaysia Sarawak, Kota \\ Samarahan, Sarawak, Malaysia
}

\author{
Dyg N. A. Zaidel \\ Department of Electrical and \\ Electronics Engineering \\ University Malaysia Sarawak, Kota \\ Samarahan, Sarawak, Malaysia \\ azdnorkhairunnisa@unimas.my \\ K. Kuryati \\ Department of Electrical and \\ Electronics Engineering \\ University Malaysia Sarawak, Kota \\ Samarahan, Sarawak, Malaysia \\ kkuryati@unimas.my
}

\author{
D.A.A. Mat \\ Department of Electrical and \\ Electronics Engineering \\ University Malaysia Sarawak, Kota \\ Samarahan, Sarawak, Malaysia \\ amdazra@unimas.my \\ L.C. Kho \\ Department of Electrical and \\ Electronics Engineering \\ University Malaysia Sarawak, Kota \\ Samarahan, Sarawak, Malaysia \\ lckho@unimas.my
}

\author{
Y. H. Lee \\ Department of Electrical and \\ Electronics Engineering \\ University Malaysia Sarawak, Kota \\ Samarahan, Sarawak, Malaysia \\ doreenlyh95@gmail.com \\ J. Annie \\ Department of Electrical and \\ Electronics Engineering \\ University Malaysia Sarawak, Kota \\ Samarahan, Sarawak, Malaysia \\ jannie@unimas.my
}

\begin{abstract}
This paper presents the design of microstrip antenna with defected ground structure (DGS) for the detection of breast tumor in microwave imaging system at operating frequency of $2.45 \mathrm{GHz}$. Four types of microstrip patch antennas have been designed using microstrip feed inset with grounding patches at $2.45 \mathrm{GHz}$ operating frequency using dielectric substrates, FR4 $(\varepsilon \mathrm{r}=4.4 \mathrm{~F} / \mathrm{m})$. The results are collected via the intensity of electric (E), magnetic fields $(H)$ and current densities. The antenna is examined with a 3D breast model structure with specific dielectric value and conductivity. From the results, it shows that antenna with design structure, Design 4 produce a good intensities values of both $E$ and $H$ fields respectively with the presence of the tumour, and gives the value of $7083 \mathrm{~V} / \mathrm{m}$ and $35.5 \mathrm{~A} / \mathrm{m}$ while without the presence of tumour is $7186 \mathrm{~V} / \mathrm{m}$ and $35.8 \mathrm{~A} / \mathrm{m}$ compare to other proposed antennas.
\end{abstract} words)

Keywords—component, formatting, style, styling, insert (key

\section{INTRODUCTION}

Breast cancer is another familiar type of cancer that is dangerous for women, after cervical cancer [1]. Cancer cells will grow and attack the breast tissue, for example the outlet of milk, lobules (milk producing factories), along with other supporting tissues such as fat tissue [1]. So far, there is no known exact cause of breast cancer, one thing that is known is that this disease arises because of cell damage and genetic changes in breast tissue.

International Agency for Research on Cancer (IARC) GLOBOCAN in 2012 recorded that breast cancer is the main health problem for women all over the world. In fact, the numbers continue to increase in the last 10 years in various parts of the world. Data indicates that among 1.7 million women diagnosed, approximately around $11.9 \%$ were cancer incidence [2]. World Health Organization data shows the prevalence of cancer breasts around the world reached 6.3 million at the end in 2012 spread across 140 countries [2]. Early detection is very important to do to reduce new cases of cancer as well as necessary precautions and early treatment. It shows that the survival rate would increase and thus reducing the mortality associated with the breast cancer if early detection is done.

Microwave imaging system (MIS) is not a new thing in the cancer detection technology as shown in Fig.1. This technique has been widely used especially for biomedical diagnosis and antenna is one of passive device used to detect the tumor. The principle behind the MIS is to use a transmitter antenna to transmit signals into the breast and receiver antenna to receive those transmitted signals after interacting with the breast. The presence of a tumor inside the body would result higher the dielectric properties compare to those of other breast's tissues due to higher signal dispersed [3].

In MIS, design factor in the antenna has caused limitations for microwaves signal that travel through the tumor to experience a change in the material dielectric property that leads to the dispersion of the incident wave that limits the image of human tissues [4]. Human tissues at $2.45 \mathrm{Ghz}$ microwave frequencies are heterogeneous and dispersive thus resulting complex field distributions. Some parts of the human body, such as the breast, are made up of many tissues with significant differences in dielectric properties with multiple scattering objects that appear as clutters and need to be compensated in the imaging algorithms [4]. The current antenna faced some problem in term of lower directivity and gain. In order, to detect the tumor inside the human breast tissue, it need a higher directivity and gain of the antenna.

In this paper, four microstrip patch antennas are designed with emphasized on the defected ground structure (DGS) as the ground plane of the antenna. The fields density is the focus 
and being analyzed to distinguish between normal and abnormal breast due to the existence of tumor.

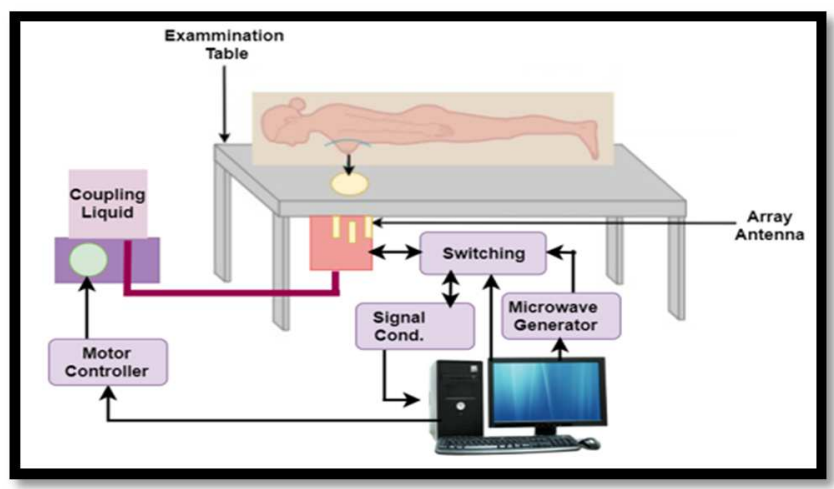

Fig. 1. Breast cancer detection prototype system [5].

\section{Designing the Antenna And the Breast ModeL STRUCTURE}

\section{A. The proposed antennas}

The microstrip patch antennas are designed with and without the existence of DGS operating at $2.45 \mathrm{GHz}$ frequency band. There are four different structures of the ground in the proposed antenna which consist of rectangular slot antenna, notch antenna, slot antenna with slotted defected ground and notch antenna with slotted defected ground. The dielectric substrate used in this research is Flame Retardant 4 (FR4) with dielectric permittivity, $\mathrm{er}$ of 4.4 , The thickness of the antenna is $1.6 \mathrm{~mm}$. Fig. 2 shows the proposed antennas. Table 1 shows the parameter of all the proposed antennas.

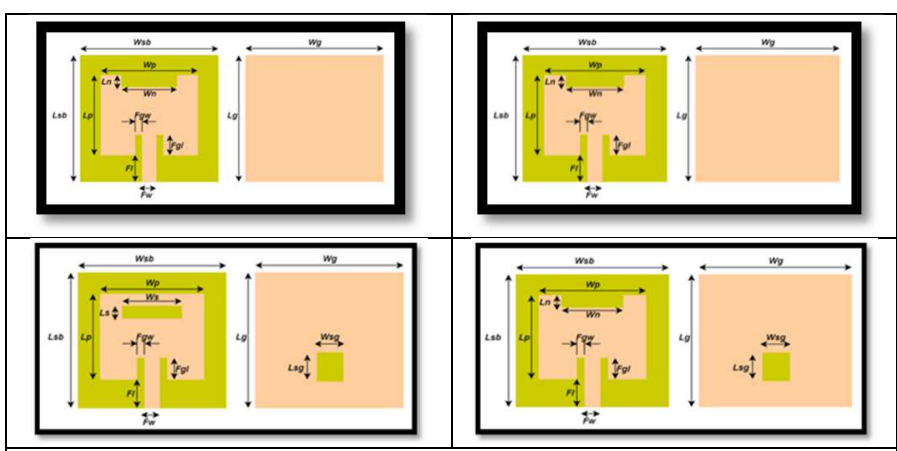

Fig. 2. Four Proposed Antennas

TABLE I

TABLE TYPE STYLES

\begin{tabular}{ll}
\hline Name & Design $(\mathrm{mm})$ \\
\hline Width substrate, $W_{s b}$ & 60 \\
Length substrate, $L_{s b}$ & 50 \\
Width patch, $W_{p}$ & 47 \\
Length patch, $L_{p}$ & 28.82 \\
Feedline width, $F_{w}$ & 3.08 \\
Feedline length, $F_{l}$ & 20 \\
Feedline gap width, $F_{q w}$ & 1 \\
Feedline gap length, $F_{q l}$ & 9.57 \\
Width notch, $W_{n}$ & 11.26 \\
Length notch, $L_{n}$ & 1 \\
Width ground, $W_{q}$ & 60 \\
Length ground, $L_{q}$ & 50 \\
Width slot ground, $W_{s, q}$ & 5.08 \\
Length slot ground, $L_{s, q}$ & 9.57 \\
\hline
\end{tabular}

\section{B. Designing the Breast Model Structure}

Fig. 3(a) and 3(b) show the breast model structure with and without tumour. This model structure is designed by considering hemisphere shape as a breast which is covered by the breast skin, breast tissue and sphere as tumor. Based on Table 2, the size of tumour is assumed to be $10 \mathrm{~mm}$, indicates the early stages of cancer. The diameter of the breast skin is $100 \mathrm{~mm}$ and the diameter of breast tissue is $90 \mathrm{~mm}$. Each of the antenna will be placed in between the breast model structure in order to study electric and magnetic field of the antennas.

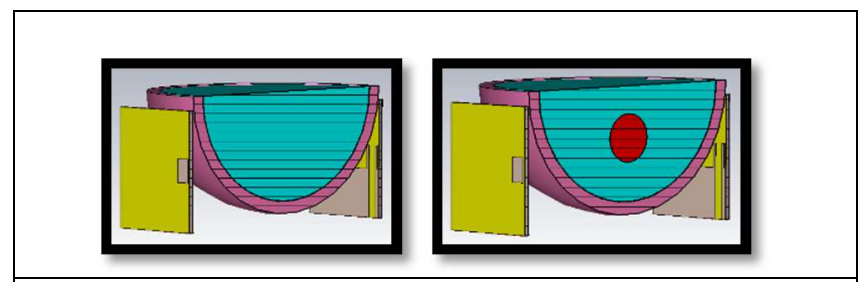

Fig. 3. (a) Breast model without tumour (b) with tumour.

TABLE II.

DIELECTRIC CONSTANT PROPERTIES OF HEALTHY BREAST MODEL STRUCTURE [6][7][8][9][10][11]

\begin{tabular}{cccc}
\hline & $\begin{array}{c}\text { Dielectric } \\
(\mathrm{F} / \mathrm{m})\end{array}$ & $\begin{array}{c}\text { Conductivity } \\
(\mathrm{S} / \mathrm{m})\end{array}$ & $\begin{array}{c}\text { Diameter } \\
(\mathrm{mm})\end{array}$ \\
\hline Breast Skin & 36 & 4 & 100 \\
Breast & 9 & 0.4 & 90 \\
Tissue & & 4 & 10 \\
Tumour & 50 & 4 & \\
\hline
\end{tabular}

\section{RESUlTS AND DisCUSSIONS}

The results are shown in Fig. 4. Table 3 summarize all data collected for the proposed antennas.

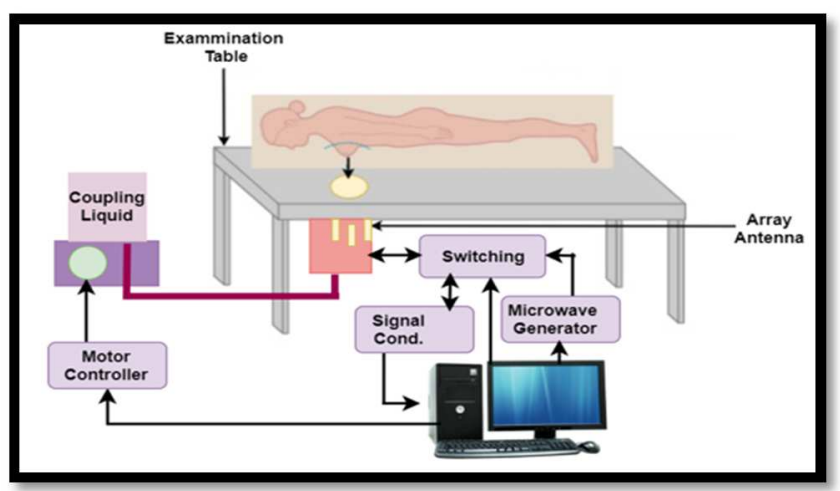

Fig. 4. S-parameter results for 4-type of design antennas.

TABLE III.

THE RETURN LOSS, BANDWIDTH DIRECTIVITY, GAIN AND EFFICIENCY OF PROPOSED ANTENNAS

\begin{tabular}{ccccc}
\hline & $\begin{array}{c}\text { Design } \\
1\end{array}$ & Design 2 & Design 3 & Design 4 \\
\hline $\begin{array}{c}\text { Return loss } \\
(\mathrm{dB})\end{array}$ & -36.88 & -22.789 & -19.023 & -14.553 \\
$\begin{array}{c}\text { Bandwidth } \\
(\mathrm{Ghz})\end{array}$ & 0.046 & 0.044 & 0.037 & 0.029 \\
$\begin{array}{c}\text { Directivity } \\
(\mathrm{dBi})\end{array}$ & 6.57 & 6.59 & 6.6 & 6.63 \\
$\begin{array}{c}\text { Gain }(\mathrm{dB}) \\
\text { Radiation } \\
\text { efficiency } \\
(\mathrm{dB})\end{array}$ & 3.292 & 3.335 & 3.322 & 3.411 \\
\hline
\end{tabular}


As shown in Table 3, Design 1 gives return loss of $36.887 \mathrm{~dB}$, Design 2 with $22.789 \mathrm{~dB}$, Design 3 with $19.023 \mathrm{~dB}$ and Design 4 it is $-14.553 \mathrm{~dB}$ respectively. The calculated directivity of Design 4 shows the most desired directivity of $6.63 \mathrm{dBi}$ followed by Design 3 with $6.6 \mathrm{dBi}$ followed by Design 2 and Design 1 with $6.59 \mathrm{dBi}$ and $6.57 \mathrm{dBi}$. In this design, Design 4 is prefer due to the DGS is placed as the ground layer of the antenna compare to Design 1. It shows better directivity and gain compare to other designs. Fig.5 shows the 3D-radiation pattern of Design 4 . At $2.45 \mathrm{GHz}$, the gain is $3.411 \mathrm{~dB}$ with far field type and $6.627 \mathrm{~dB}$ directivity.

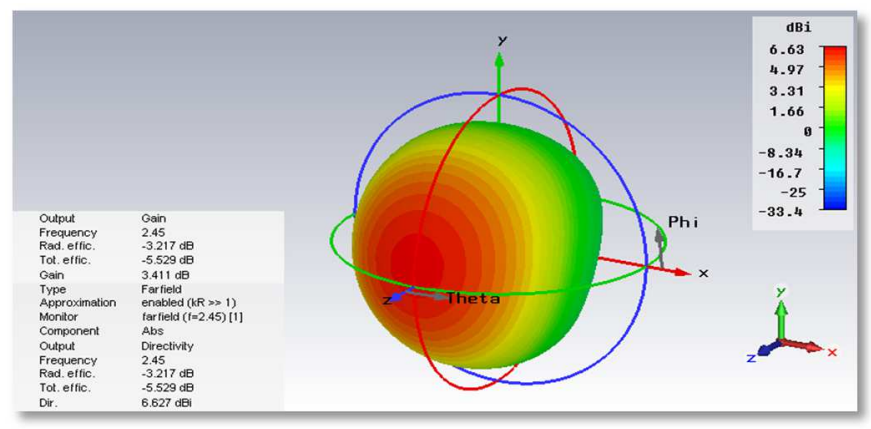

Fig. 5. Radiation pattern of the Design 4

The variation in $\mathrm{E}$ and $\mathrm{H}$ fields for Design 4 is shown in Figure 6, and 7, (with levels of intensities). It shows maximum of E-fields of $7186 \mathrm{~V} / \mathrm{m}$ and $7083 \mathrm{~V} / \mathrm{m}$ and $\mathrm{H}$-fields of $35.47 \mathrm{~A} / \mathrm{m}$ and $35.81 \mathrm{~A} / \mathrm{m}$ intensities with and without tumor respectively. Table 4 summarize all the results for the proposed antennas.
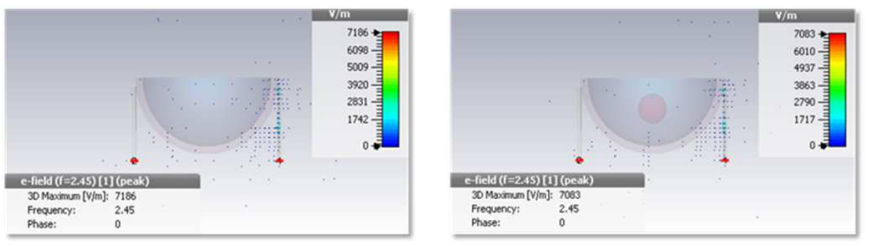

Fig. 6. E-field of Design 4 (a) without tumour (b) with tumour.
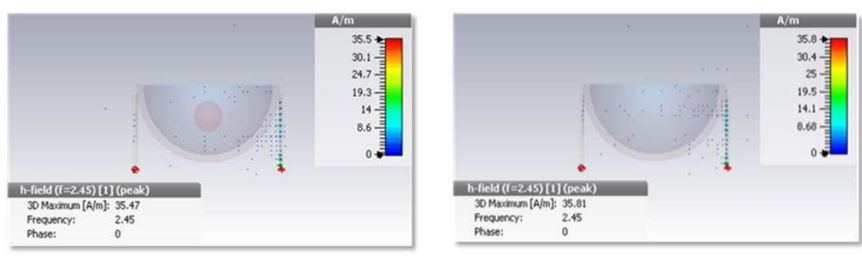

Fig. 7. H-field of Design 4 (a) without tumour (b) with tumour.

TABLE IV.

THE E-FIELD, H-FIELD AND CURRENT DENSITY OF PROPOSED ANTENNA.

\begin{tabular}{|c|c|c|c|c|c|c|}
\hline & \multicolumn{2}{|c|}{$\begin{array}{l}\text { Electric field, } \\
\text { (E-field V/m) }\end{array}$} & \multicolumn{2}{|c|}{$\begin{array}{c}\text { Magnetic field, } \\
\text { (H-field A/m) }\end{array}$} & \multicolumn{2}{|c|}{$\begin{array}{l}\text { Current } \\
\text { density } \\
\left(\mathrm{A} / m^{2}\right)\end{array}$} \\
\hline $\begin{array}{c}\text { Breast } \\
\text { Structure }\end{array}$ & $\begin{array}{c}\mathrm{NO} \\
\text { tumour }\end{array}$ & Yes & $\begin{array}{c}\mathrm{NO} \\
\text { tumour }\end{array}$ & Yes & $\begin{array}{c}\mathrm{NO} \\
\text { tumour }\end{array}$ & Yes \\
\hline $\begin{array}{c}\text { Antenna } \\
1\end{array}$ & 7261 & 6855 & 50.8 & 52.2 & 458 & 464 \\
\hline $\begin{array}{c}\text { Antenna } \\
2\end{array}$ & 6858 & 6704 & 35 & 36 & 463 & 492 \\
\hline Antenna & 6898 & 6834 & 49.1 & 49.9 & 439 & 442 \\
\hline 3 & 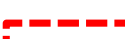 & " שת & $=$ & $-\pi$ & - - - & $-=$ \\
\hline $\begin{array}{c}\text { Antenna } \\
4\end{array}$ & 7186 & 7083 & 35.8 & 35.5 & 443 & 476 \\
\hline
\end{tabular}

From the results, it shows that the result of antenna Design 1, Design 2, and Design 3 show the decreases value of E-field but increases value in $\mathrm{H}$-field and current density with and without the presence of tumour. Although Design 1, gives good result, the proposed technique emphasize in this research is the introduction of DGS, thus, Design 4 is chosen. It is also because of directivity and gain of Design 4 . The field density with the presence of the tumour of $7083 \mathrm{~V} / \mathrm{m}$ and $35.5 \mathrm{~A} / \mathrm{m}$ while without the presence of tumour is $7186 \mathrm{~V} / \mathrm{m}$ and 35.8 $\mathrm{A} / \mathrm{m}$. Design 4 is fabricated and shown in Fig. 9.

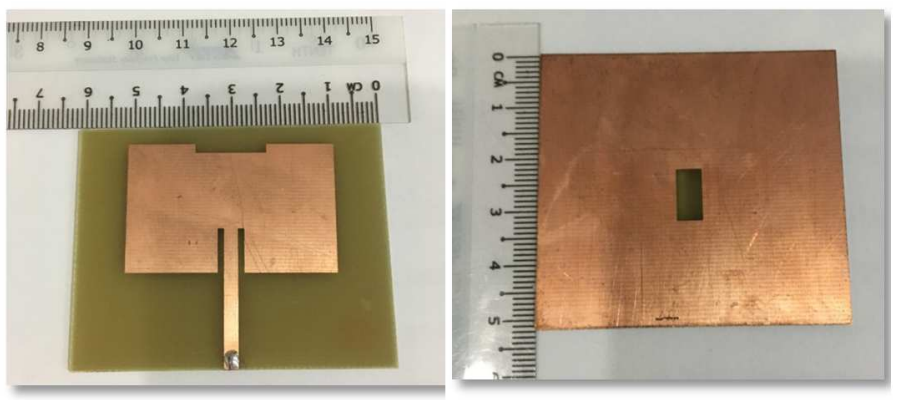

Fig. 8. Design 4

The mutual coupling among the annular array configurations in transmission mode for Design 4 is also simulated as shown in Fig. 10. In this figure, the antennas are placed at certain distance to reduce the mutual coupling during the examination between antennas. The green line indicates one antenna and both blue and red lines indicate other antennas

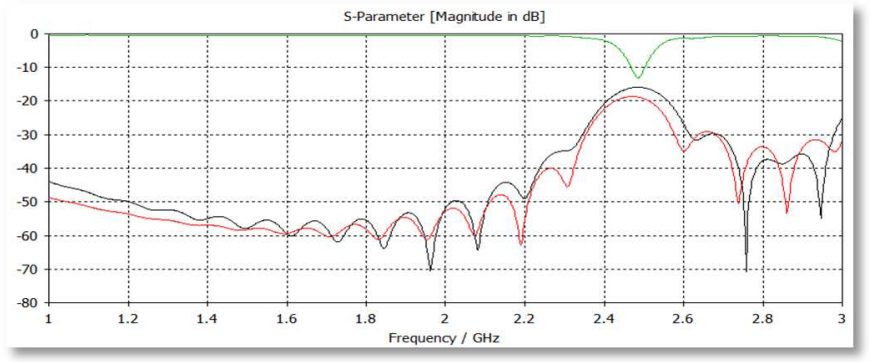

Fig. 9. Mutual coupling of the array

\section{CONCLUSION}

In this research, four different designs of patch antennas are proposed. Among all designs, it shows that Design 4 (with DGS proposed) shows good results directivity and gain, Efield and $\mathrm{H}$-field with and without the presence of tumour. It gives the results of high electric and magnetic fields of $7083 \mathrm{~V} / \mathrm{m}, 35.5 \mathrm{~A} / \mathrm{m}$ due to the existence of tumor) and $7186 \mathrm{~A} / \mathrm{m}, 35.8 \mathrm{~A} / \mathrm{m}$ (without tumour) respectively. The mutual coupling of Design 4 is also calculated and to conclude, Design 4 is the most suitable compare to other proposed antennas and will be used as the front-end of MIS.

\section{REFERENCES}

[1] M. Al-Hajj, M. S. Wicha, A. Benito-Hernandez, S. J. Morrison, and M. F. Clarke, "Prospective identification of tumorigenic breast cancer cells," Proc. Natl. Acad. Sci., vol. 100, no. 7, pp. 3983-3988, 2003.

[2] L. A. Torre, F. Bray, R. L. Siegel, J. Ferlay, J. Lortet-Tieulent, and A. Jemal, "Global cancer statistics, 2012.," CA. Cancer J. Clin., vol. 65 , no. 2, pp. 87-108, 2015. 
[3] B. . Yuvamaliga, "Design of Flexible Antenna Array for Early Diabetic Foot Detection," Int. J. Res. Appl. Sci. Eng. Technol., vol. V, no. X, pp. 1370-1376, 2017.

[4] Z. Wang, E. G. Lim, Y. Tang, and M. Leach, "Medical applications of microwave imaging," Sci. World J., vol. 2014.

[5] A. Abbosh, B. Mohammed, and M. Bialkowski, "Imaging System -22 I 1,”pp. 199-202, 2011.

[6] S. Shrestha and M. Agarwal, "Microstrip Antennas for Direct Human Skin Placement for Biomedical Applications," Prog. Electromagn. Res. Symp., no. iii, pp. 926-931, 2010.

[7] M. Klemm, I. J. Craddock, J. a Leendertz, A. Preece, and R. Benjamin, "Radar-Based Breast Cancer Detection Using a Hemispherical
Antenna Array - Experimental Results," Antennas Propagation, IEEE Trans., vol. 57, no. 6, pp. 1692-1704, 2009.

[8] H. Bahrami, E. Porter, and A. Santorelli, "Flexible Sixteen Antenna Array for Microwave Breast Cancer Detection," vol. 62, no. 10, pp. 2516-2525, 2015.

[9] R. Çalışkan, S. S. Gültekin, D. Uzer, and Ö. Dündar, "A Microstrip Patch Antenna Design for Breast Cancer Detection," Procedia - Soc. Behav. Sci., vol. 195, pp. 2905-2911, 2015

[10] E. Porter, "Microwave breast tumor detection : simulation and design of experiments with tissue phantoms," no. June, 2010 .

[11] "Progress In Electromagnetics Research C, Vol. 30, 189-199, 2012," vol. 30, no. May, pp. 189- 199, 2012. 